\title{
A Review of the Literature About the Theoretical Generation and Influence of Scientific Research Training Environment
}

\author{
Yang Yang ${ }^{1, *}$, Zhang $\mathrm{Yu}^{2}$ \\ ${ }^{1}$ The School (party committee) office, Guangzhou City Construction College, Guangzhou, Guangdong 510925, China \\ ${ }^{2}$ School of Information Engineering, Guangzhou City Construction College, Guangzhou, Guangdong 510925, China \\ *Corresponding author.Email:997066635@qq.com
}

\begin{abstract}
The Research Training Environment Theory proposed by Charles J. Gelso, a well-known professor in the University of Maryland, mainly includes eight elements: (1)faculty modeling of appreciate scientific behavior and attitudes; (2)Positive reinforcement for scientific research activities; (3)Early and minimal participation in research; (4)The wedding of science and practice; (5)Looking inward for research ideas; (6)Science as a partly social experience; (7)The flawed and limited nature of every research study; (8)Teaching varied approaches to research. A large number of studies have shown that there is a significant correlation among scientific research training environment, scientific self-efficacy and scientific research attitude. Scientific research training environment influences the research productivity and scientific research output of graduate students.
\end{abstract}

Keywords: Scientific research training environment, theoretical generation, influence, review of the literature

\section{INTRODUCTION}

In recent years, the rapidly developing postgraduate education has made important contributions to the cultivation of senior talents, the creation of high-tech achievements and the provision of high-level social services. However, at the same time, the overall quality of postgraduate training has declined, and the lack of scientific research ability has also become a recognized fact. How to improve the scientific research ability of graduate students has become a major and urgent task at present?

Then, what kind of training environment is conducive to cultivating graduate students' interest in scientific research and improving their scientific research ability? Based on this thinking, the author searched relevant literatures and found that domestic researches focused on the influence of external factors such as curriculum setting, tutor guidance and academic atmosphere on students' scientific research ability by using the word "scientific research environment". The researches were relatively scattered and lacked unified theoretical guidance. However, foreign scholars put forward the concept of "scientific research training environment" earlier, and defined its internal elements and dimensions clearly. Empirical studies on the impact of scientific research training environment on graduate students' self-efficacy of scientific research, scientific research interest and scientific research productivity are also quite abundant.

\section{THE ORETICAL GENERATION OF SCIENTIFIC RESEARCH TRAINING ENVIRONMENT}

The Theory of Scientific Research Training Environment was first put forward by Charles j. Gelso, a famous professor of psychology at the university of Maryland. According to Gelso, the research training environment is a variety of factors that influence students' attitude towards research in the process of postgraduate training, which come from different departments and schools. In order to change students' attitude towards scientific research and improve their enthusiasm and productivity, Gelso proposed that an effective environmental model for scientific training should include at least the following eight factors [1]:

Faculty modeling of appreciate scientific behavior and attitudes. This factor is mainly reflected in the fact that teachers like to discuss academic issues, are interested in 
scientific research and actively participate in scientific research activities; Teachers are willing to share their experiences of failure or success in research and invite students to be partners in their research projects.

Positive reinforcement for scientific research activities. Schools or departments should give sufficient positive reinforcement to students' scientific research behavior, provide sufficient opportunities for students to conduct scientific research. In addition to material support, the strengthening of interpersonal relationships may have a greater impact.

Early and minimal participation in research. This factor is reflected in the following: in the early years of graduate enrollment, the university should encourage students to participate in scientific research activities appropriate to their professional level as early as possible, and cooperate with teachers or senior students.

The wedding of science and practice. On the one hand, practice is an important source of research ideas; On the other hand, scientific research can in turn guide practice. Postgraduate education should focus on how to make scientific research relevant to practice, and show the interaction and promotion effect of scientific research and practice to students.

Looking inward for research ideas. This is mainly reflected in the fact that teachers respect students' own research interests and encourage them to study the issues they are interested in.

Science as a partly social experience. This is mainly reflected in that schools should provide students with various opportunities to meet their social and interpersonal needs in the process of scientific research through research teams, good teacher-student relations or some informal academic exchanges.

The flawed and limited nature of every research study. Schools and teachers should make it clear to students that there are inevitable problems with any research, and that teachers should not put too much pressure on students to do research that is too perfect.

Teaching varied approaches to research. Schools should familiarize students with a variety of research methods, which can not only enable students to have more abilities and qualities after graduation, but also help them to adapt to the personality characteristics and individual preferences of graduate students.

Gelso found that there are only six factors which results to prove effective and support in empirical research in the above eight factors, except "Science as a partly social experience" and "Looking inward for research ideas".

\section{THE INFLUENCE OF RESEARCH TRAINING ENVIRONMENT}

\subsection{The influence of research training environment on research self-efficacy and research attitude}

A large number of studies have shown that there is a significant correlation among scientific research training environment, scientific research self-efficacy and scientific research attitude.

Royalty found research training environment has an impact on students' research attitude, research productivity and research self-efficacy, among which The Faculty modeling has the most significant positive impact on students' research attitude.[2]

Lent believed that the learning environment was very important for one's career development. Various experiences in the previous learning environment would affect people's self-efficacy, and then affect their future development and achievement. In particular, when this particular experience was positively reinforced, they had a greater sense of self-efficacy in the relevant field.[3]

Shivy found that the factors of interpersonal interaction experience in the scientific research training environment had the greatest impact on students' sense of scientific research self-efficacy, and teaching seminars strengthened the interpersonal relationship.[4]

Betz also pointed out that the various factors offered in the research training environment not only help students enhance their research ability and quality, but also foster a firm sense of research self-efficacy.[5]

Bieschke and Bishop found that the research training environment and research career interest also had a direct impact on the research self-efficacy of graduate students.[6]

Vaccaro studied the relationship between research training environments, self-efficacy and interest in research, as well as differences in demographic background characteristics such as age, gender, educational experience, grade level, academic activities, and career motivation. He found that the years of doctoral students in school had no significant effect on the perception of the research self-efficacy and the research training environment of postgraduates, while the age of doctoral students and the number of courses they had taken did.[7]

There are very few direct related studies in China. Wang ya-jing found that the research conception played an intermediary role between the factor "Looking inward for research ideas" and the research output, while the scientific research implementation and the presentation of results play an intermediary role between the factors of diversified research methods and the scientific research output of doctoral students.[8]

According to a survey of 412 academic graduate students by Gong Liang, there is a big gap between Chinese and 
American universities in factors such as "Faculty modeling" "Positive reinforcement" and "Looking inward for research ideas".[9]

\subsection{The influence of research training environment on research productivity and research output}

In addition to influencing the research self-efficacy and interest of postgraduates, the research training environment will eventually affect the research productivity or output of postgraduates.

Gelso believed that the early and appropriate nature of scientific research training, scientific research as a social experience and diversified scientific research methods had the greatest impact on scientific research productivity.[10]

Kerbs studied the influence of occupational personality and scientific research training environment on scientific research productivity. Through the investigation of 260 consulting psychologists, he found that the investigative interest in occupational personality was positively correlated with scientific research productivity, while the social interest was negatively correlated with scientific research productivity.[11]

Mallinckrodt has studied gender differences in the impact of research training environments on research productivity. Study found that for men, the role of "faculty modeling of appreciate scientific behavior and attitudes" and "Science as a partly social experience" influence the scientific research productivity.[12]

Khan summarized effective scientific research training environment can make students interested in and engaged in scientific research, increase their sense of scientific research self-efficacy, and thus improve their scientific research ability.[13]

\section{SUMMARY}

In conclusion, the study on scientific research and training environment in foreign countries is much richer than that in China, where only two articles have analyzed the influence of research training environment on the research self-efficacy and research interest of postgraduates from the theoretical and empirical perspectives. Scientific research training environment theory abroad was applied extensive especially in the field of counseling psychology. There are abundant empirical studies on the research and training environment and a large number of foreign studies have proved that the research and training environment has a significant impact on research attitude, research self-efficacy and research productivity. While the division of domestic research environment is mainly divided into hard environment and soft environment, macro environment and micro environment. As for the internal elements and dimensions contained in the scientific research environment, there is still no clear definition and unified conclusion, and the research is scattered and not systematic enough. Therefore, the empirical effect of the scientific research training environment and the difference of the research training environment at home and abroad are worth further discussion.

\section{REFERENCES}

[1] GELSO C J. Research in counseling: Methodological and professional issues[J]. The Counseling Psychologist, 1979, 8(3): 7-35.

[2] ROYALTY G M, GELSO C J, MALLINCKRODT $\mathrm{B}$, et al. The Environment and the Student in Counseling Psychology Does the Research Training Environment Influence Graduate Students' Attitudes Toward Research $[\mathrm{J}]$. The Counseling Psychologist, 1986, 14(1): 9-30.

[3] LENT R W, BROWN S D, HACKETT G. Toward a unifying social cognitive theory of career and academic interest, choice, and performance[J]. Journal of Vocational Behavior, 1994, 45(1): 79-122.

[4] SHIVY V A, WORTHINGTON E L, WALLIS A B, et al. Doctoral research training environments (RTEs): Implications for the teaching of psychology[J]. Teaching of Psychology, 2003, 30(4): 297-302.

[5] BETZ N E. Increasing research involvement and interests among graduate students in counseling psychology[J]. 1997, 25(1): 88-93.

[6] BISHOP R M, BIESCHKE K J. Applying social cognitive theory to interest in research among counseling psychology doctoral students: A path analysis[J]. Journal of Counseling Psychology, 1998, 45(2): 182.

[7] VACCARO N. The relationship between research self-efficacy, perceptions of the research training environment and interest in research in counselor education doctoral students: An ex-post-facto, cross-sectional correlational investigation[M]. ProQuest, 2009

[8] WANG Yajing. Research on the influence of research training environment and supervisor support on doctoral research output[J]. Journal of Northwestern Polytechnical University (Social Sciences), 2015, 35(3): 99-104.

[9] Gong Liang, Zhang Wanhong, Li Qing. 
Investigation and analysis on the cultivation environment of academic graduate students[J]. Academic Degrees \& Graduate Education, 2015, (11): 10-17.

[10] Gelso C J, Raphael R, Black S M, et al. Research training in counseling psychology: Some preliminary data[J]. Journal of Counseling Psychology, 1983, 30(4): 611-614.

[11] Krebs P J, Smither J W, Hurley R B. Relationship of vocational personality and research training environment to the research productivity of counseling psychologists[J]. Professional Psychology: Research and Practice, 1991, 22(5): 362-367.

[12] Mallinckrodt B, Gelso C J. Impact of research training environment and Holland personality type: A 15-year follow-up of research pr:oductivity[J]. Journal of Counseling Psychology, 2002, 49(1): 60-70.

[13] KHAN J H. Predicting the scholarly activity of counseling psychology students: A refinement and extension[J]. Journal of Counseling Psychology, 2001, 48(3):344. 